\title{
Settlement preferences of leeches (Clitellata: Hirudinida) for different artificial substrates
}

\author{
Żaneta Adamiak-Brud • Izabela Jabłońska-Barna • \\ Aleksander Bielecki $\cdot$ Janusz Terlecki
}

Received: 1 September 2014/Revised: 3 June 2015/Accepted: 3 June 2015/Published online: 28 July 2015

(C) The Author(s) 2015. This article is published with open access at Springerlink.com

\begin{abstract}
We examined the settlement preferences of leeches by analysing colonization patterns on artificial substrates. The intention was to check whether the type of material, texture and size of artificial substrates would influence the abundance of leeches. To test substrate type preferences, we used the following nine artificial substrates: polyester, polycarbonate, aluminium, glass, rubber, steel, polyethylene, ceramics and polypropylene. In addition, substrates of different textures (structural vs. smooth) and sizes $\left(900,400,100 \mathrm{~cm}^{2}\right)$ were used. We found that rubber, polyethylene and aluminium were most frequently chosen by the leeches. Surface structure and size of the objects were other factors which determined substrate selection by these organisms. Leeches more readily inhabited rough surfaces and the surfaces of smaller-sized objects. The species composition of leech assemblages on analysed artificial
\end{abstract}

Handling editor: Checo Colón-Gaud

Ż. Adamiak-Brud $(\bowtie) \cdot$ A. Bielecki

Department of Zoology, University of Warmia and

Mazury in Olsztyn, ul. Oczapowskiego 5, 10-719 Olsztyn,

Poland

e-mail: zaneta.adamiak-brud@o2.pl

I. Jabłońska-Barna $\cdot$ J. Terlecki

Department of Applied Ecology, University of Warmia and Mazury in Olsztyn, ul. Oczapowskiego 5,

10-719 Olsztyn, Poland substrates was dominated by predatory taxa of the genus Erpobdella and Helobdella.

Keywords Artificial materials - Substrate preferences $\cdot$ Settling behaviour - Substrate roughness and size

\section{Introduction}

Leeches are among the most numerous inhabitants of the littoral zone in aquatic ecosystems and they are important components of the food webs of different types of water bodies (Koperski, 2003; Strzelec et al., 2010). These predators and bloodsuckers attack various groups of hydrobionts and are themselves prey to many carnivores (Chernaya \& Koval'chuk, 2009; Siciński, 2009). Previous studies have shown that one of the most important environmental factors which determine the number and diversity of this taxon is the presence of a solid substrate (Pawłowski, 1936; Sawyer, 1986; Krodkiewska, 2003; Koperski, 2010). Most leeches inhabit stones, pieces of wood and other hard underwater substrates (Bielecki et al., 2008; Beracko \& Košel, 2011; Utevsky et al., 2012). Many studies have also highlighted the role of macrophytes as agents increasing the abundance and biological diversity of Hirudinida (Sawyer, 1986; Bielecki et al., 2004). Leeches clearly avoid soft and unstable bottoms, including sand and silt, which do not allow 
them to attach their suckers and, as a result, significantly reduce their ability to move freely, feed or escape from predators (Agapow, 1980; Brönmark, 1992).

Anthropogenic pressure on the environment has resulted in an increased amount of solid waste introduced to aquatic ecosystems. The introduction of solid waste can replace natural habitats and cause fragmentation (e.g. changing the nature of the substrate, creating barriers), resulting in the disappearance of certain taxa and a decline in local biodiversity (Beaven et al., 2000; Brauns et al., 2007). However, most often they create new habitats and increase the space available for many plants and invertebrates (Winston, 1982; Chapman \& Clynick, 2006; Jatulewicz, 2007; Czarnecka et al., 2009). Matysiak (1985), Bertman \& Bielecki (1997), CzerniawskaKusza (2004) have shown that leeches find favourable conditions for life on anthropogenic wastes and often prefer them, especially when the bottom is not suitable, e.g. sandy bottom (Czarnecka et al., 2009). Artificial substrates may also play a prominent role in the reproduction of leeches. Most species of the family Erpobdellidae and Piscicolidae deposit their cocoons on a hard surface (Sawyer, 1986; Young, 1988; Dimitriu \& Shain, 2004; Mason et al., 2005). Waste as a sustainable and stable element of the environment seems to form a favourable place for leeches to leave cocoons. Results by Koperski (2003) have shown that the density of cocoons of the family Erpobdellidae laid on the artificial surface was several times higher when compared to those laid on other biotic and abiotic elements of the environment.

Factors influencing the settlement of leeches on different habitats are still poorly known. Most attention has been devoted to biological and chemical agents (Mazzoni et al., 2005; Garcia-Perez et al., 2007; Bisson \& Torre, 2011; Bisson et al., 2012) and the role of light (Pawłowski, 1936; Elliott, 1973; Sawyer, 1986; Bielecki, 1999; Bielecki et al., 2011a). However, there is a lack of information concerning physical properties of substrates, particularly those of anthropogenic origin, which often represent the more frequent substrate type for settlement by these invertebrates.

The purpose of this study was to investigate leech settlement on several substrates, which could be potentially introduced into aquatic ecosystems as a result of human activity. We hypothesized that leech numbers would depend on material composition of artificial substrate (experiment 1), texture (experiment 2) and size of the tested objects (experiment 3 ).

\section{Materials and methods}

Study site

The study was carried out in Lake Ukiel, the deepest and largest water body (maximum depth $43 \mathrm{~m}$, mean depth 10.6 and surface area 412 ha) in Olsztyn city (Mazurian Lake District, northeastern Poland). Lake Ukiel is characterized by high species diversity and abundance of leeches (Żółtowski, 1965; Bielecki \& Dzika, 2000; Bielecki et al., 2011b). Sampling was conducted in the northwestern part of the lake called Gutkowskie $\left(54^{\circ} 62^{\prime} \mathrm{N} ; 20^{\circ} 66^{\prime} \mathrm{E}\right)$ (Fig. 1). The selected study site possessed a substrate consisting of relatively uniform portions of sand, gravel and small stones. The emerged phytolittoral comprises sparse patches of Phragmites australis (Cav.) Trin. Ex Steudel, with no submerged macrophytes. During the study, fluctuation in various physical and chemical characteristics and water level were not noted (Table 1).

\section{Experimental design}

Settlement plates were exposed in the near shore area of Lake Ukiel from September to October in 2013. Leeches were collected from the plate's surface during five separate sampling events, occurring every twelve days starting September 13 and concluding October 31. The settlement unit composed of plates attached directly to the bottom, arranged horizontally, in three rows, parallel to the shore of the lake. The first row of plates was anchored to the bottom of the lake at a depth of $30 \mathrm{~cm}$. The plates in the rows were spaced about $5 \mathrm{~cm}$ from each other. Schemes of the arrangement of plates in each variant of experiments are shown in Figs. 2, 3 and 4. After each collection, the plates were cleaned of contaminants and organisms that deposited on them by brush. Specimens collected from the three plates made of the same type of analysed substrate were combined into one composite sample. There were 5 replicates for each substrate type, representative of the 5 collection dates spanning the 12 sampling day intervals per collection period. 


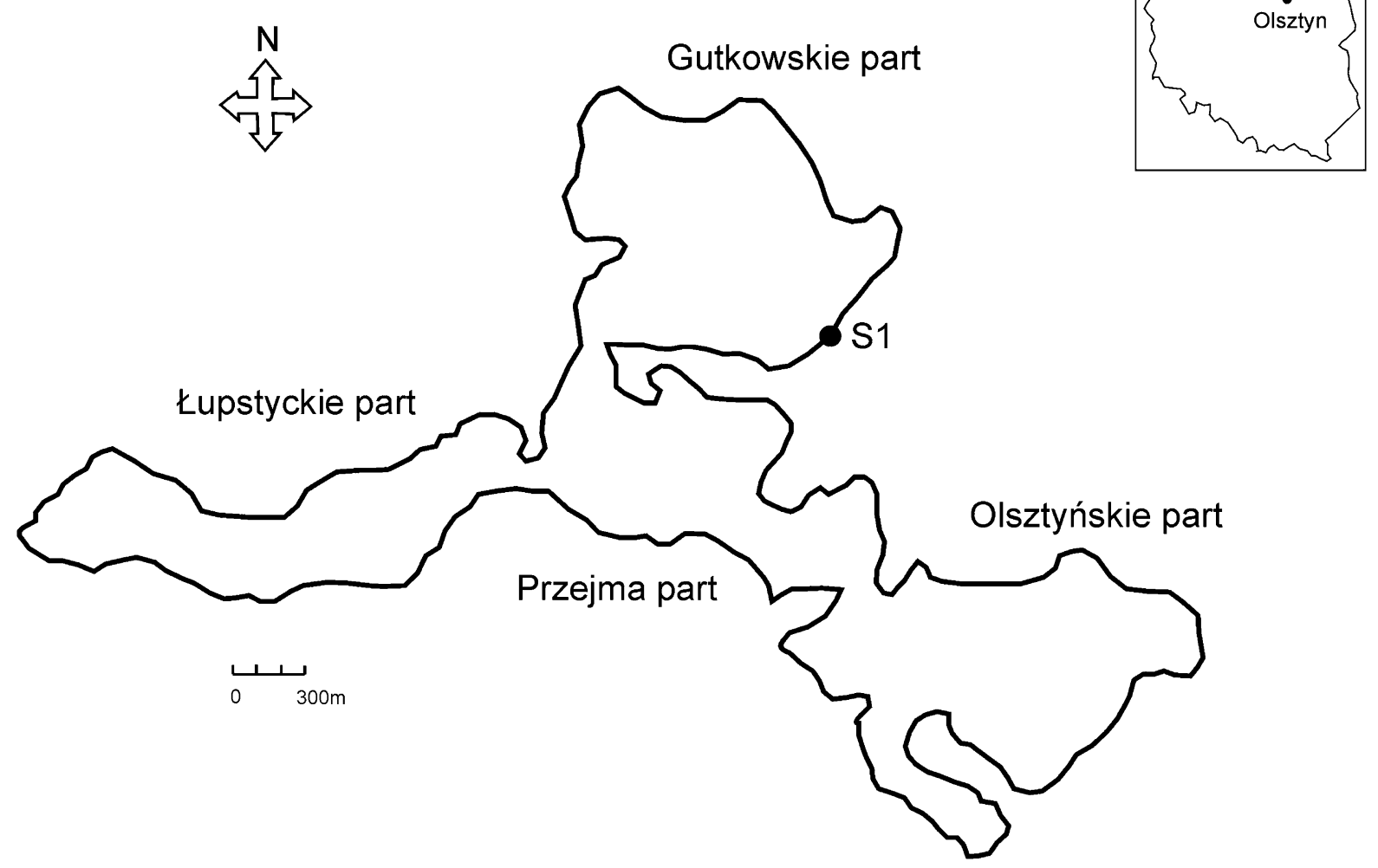

Fig. 1 Map of Lake Ukiel in northeastern Poland, with location of study site (S1)

Table 1 Physical and chemical parameters of the water during experiment period

\begin{tabular}{lcl}
\hline Parameter & $x$ & SD \\
\hline $\mathrm{pH}$ & 9.0 & 0.0084 \\
Dissolved oxygen $(\mathrm{mg} / \mathrm{l})$ & 10.6 & 1.0840 \\
Conductivity $(\mu \mathrm{S} / \mathrm{cm})$ & 240 & 1.4832 \\
Total suspended solids $(\mathrm{mg} / \mathrm{l})$ & 158 & 0.9771 \\
Temperature $\left({ }^{\circ} \mathrm{C}\right)$ & 14.8 & 3.4928 \\
\hline
\end{tabular}

$x$ mean, $S D$ standard deviation, $n=5$

In the first experiment, to test the preference of material, the following substrates were used: 1-polycarbonate (hard, rigid and transparent), 2-polyester (soft and flexible), 3-aluminium (hard and rigid), 4-glass (hard, rigid and transparent), 5-rubber (hard and flexible), 6-steel (hard and rigid), 7-polyethylene (hard and rigid), 8-ceramics (hard and rigid) and 9-polypropylene (hard and rigid) - Fig. 2. The size of one plate was $300 \times 300 \times 2 \mathrm{~mm}$ with exception to ceramic plates which had a different thickness than the rest of the elements $(300 \times 300 \times 5 \mathrm{~mm})$. We could not prepare or purchase a proper thickness of this type of plates. To analyse the effect of texture on settling preferences, in the second experiment, three sets of settlement units were constructed that comprised plates of (1) smooth and frosted glass, (2) smooth and rough aluminium and (3) smooth and riffled rubber (Fig. 3). The riffle height on the plates was $1 \mathrm{~mm}$, whereas the distance between two riffles was $3 \mathrm{~mm}$. The third experiment tested how plate size affected the density of leeches. Polyethylene, polypropylene, aluminium and glass settlement units of three sizes were deployed at the bottom $(300 \times 300 \times$ $2 \mathrm{~mm}, 200 \times 200 \times 2 \mathrm{~mm}, 100 \times 100 \times 2 \mathrm{~mm})-$ Fig. 4. Leeches collected from the plates were moved into the laboratory where they were relaxed in $10 \%$ ethyl alcohol (10 min) and preserved in 70\% ethyl alcohol. Collected individuals were classified to the species level based on Pawłowski (1936). 
Fig. 2 Experimental design and position of plates used to test for leech settlement preferences based on substrate type; $P C$ polycarbonate, $P E S$ polyester, $A L$ aluminium, $G L$ glass, $R U$ rubber, $S T$ steel, $P E$ polyethylene, $C E R$ ceramics, $P P$ polypropylene

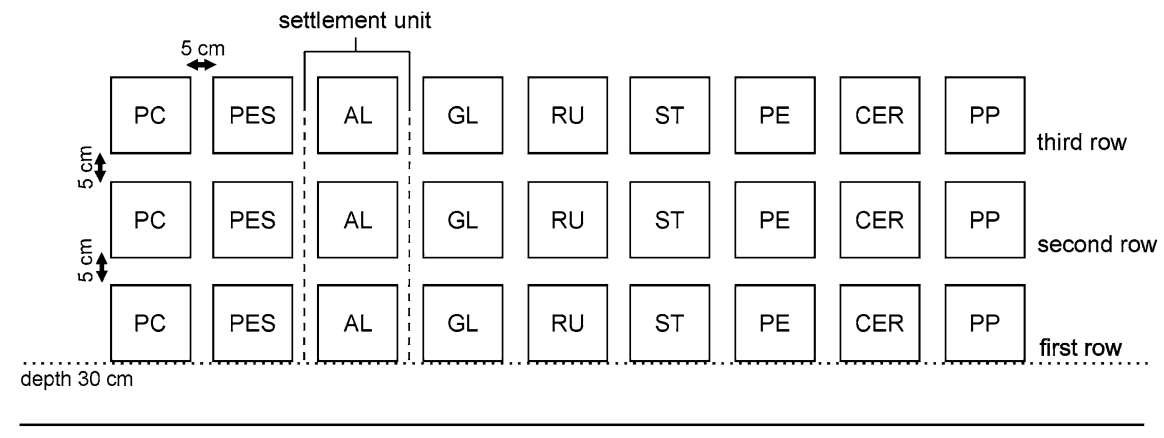

lake shore

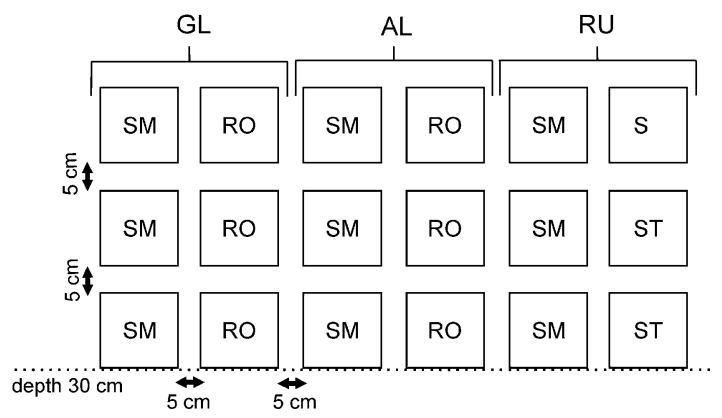

lake shore

Fig. 3 Experimental design and position of plates used to test for leech settlement preferences based on substrate texture; $G L$ glass, $A L$ aluminium, $R U$ rubber, $S M$ smooth, $R O$ rough, $R I$ riffled

Statistical analysis

Due to the heterogeneity of variance (Levene test, $P=0.0004)$, a Kruskal-Wallis test was used for assessing the significant differences in the abundance of leech assemblages on the particular materials (experiment 1). In the case of significant results, we applied a post hoc multiple comparison of mean ranks for all groups. Differences between the number of individuals collected from a particular material with a smooth and structural surface (experiment 2) and differences between the leech number and density on plates of different sizes (experiment 3) were compared using two-way analyses of variance (ANOVA) (factors: material and texture in experiment 2 , material and size in experiment 3 ). To avoid violations of ANOVA (checked with Levene test), we log-transformed the data for both analyses. When an overall ANOVA produced significant results, a Turkey's post hoc test was used to find the difference between the particular groups. The results were regarded as statistically significant at $P<0.05$. Statistical analyses and figures were made using STATISTICA 10 PL, (StatSoft, Inc. (2011), STATISTICA (data analysis software system), version 10. www.statsoft.com).

\section{Results}

In the first experiment, a total of 512 leeches were collected. These individuals were represented by five assumptions of normality and homoscedasticity
Fig. 4 Experimental design and position of plates used to test for leech settlement preferences based on substrates size: $P E$ polyethylene, $P P$ polypropylene, $A L$ aluminium, $G L$ glass, $A$ plate size $300 \times 300 \mathrm{~mm}$, $B$ plate size $200 \times 200 \mathrm{~mm}$, $C$ plate size $100 \times 100 \mathrm{~mm}$

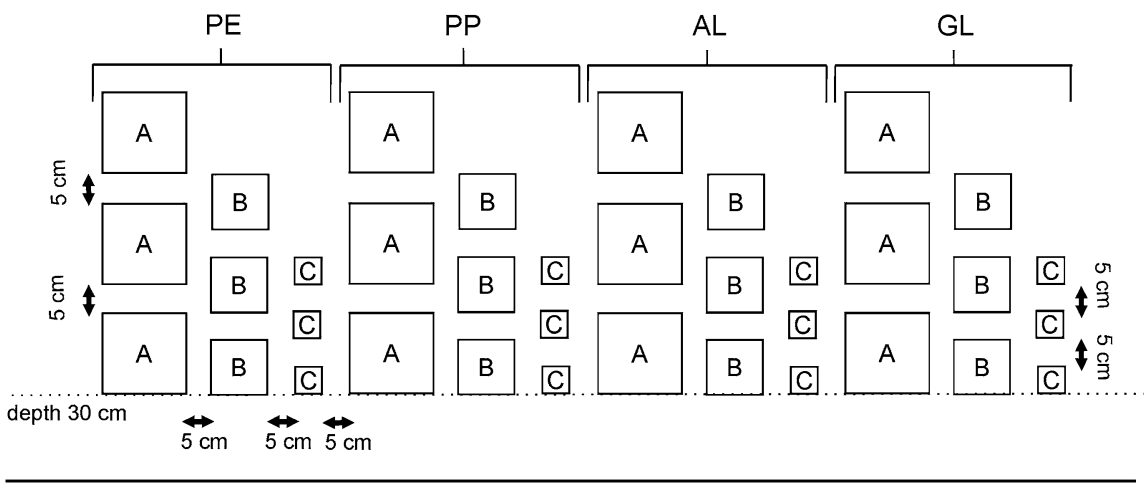

lake shore 
families and twelve leech species. In the analysed assemblages, the most numerous species collected were Erpobdella octoculata, E. nigricollis and Helobdella stagnalis accounting for $88.67 \%$ of total collected individuals. The polyester substrates differed significantly in the number of leeches from polyethylene, aluminium and rubber (Kruskal-Wallis test: $H=24.47 ; P=0.0019$ ). Polyester was significantly less settled with leeches than other materials mentioned above (Fig. 5).

The maximum number of species, nine and eight, was found on aluminium, polyethylene, rubber and ceramics. The minimal number, two and three, was found on polyester and steel (Table 2). E. octoculata and E. nigricollis were dominant taxa found across all substrate types (Table 2). However, the percentage of E. octoculata and E. nigricollis in the leech assemblages that inhabited various substrates was different, ranging from 20 to $68.18 \%$ and 10.91 to $80 \%$, respectively (Table 2). In addition to these two species, $H$. stagnalis also had a high percent of occurrence, ranging from 6.45 to $19.57 \%$. However, this taxon was not present in all the tested substrates (Table 2).

Deliberations about which substrate the species prefer were conducted based on the four species accounting for the maximum percentage number and frequency of occurence (Table 2, 3). E. octoculata was found in the highest proportions on the polyethylene and rubber substrates were these accounted respectively for 21.4 and $22.57 \%$ of total assemblage (Table 3). Other materials were settled less by the individuals of E. octoculata, where the species never exceeded $15 \%$ of the total assemblage. E. nigricollis were found in the highest proportions in rubber $(25.00 \%)$, aluminium $(20.31 \%)$ and polyethylene $(17.19 \%)$, and never exceeded $15 \%$ in all other substrates (Table 3).

The maximum percentage of all the collected specimens of $H$. stagnalis was recorded, similar to $E$. octoculata, on polyethylene, aluminium and rubber, $31.88,26.09$ and $18.84 \%$, respectively. There were not any individuals of $H$. stagnalis on polyester and steel (Table 3). The percentage number of $H$. stagnalis individuals on the other substrates did not exceed $9 \%$ of the total colonizing assemblage. The maximum number of E. monostriata inhabited rubber, polyethylene and polypropylene (Table 3). On these substrates, leeches of this species ranged from 20.69 to $24.14 \%$. The occurrence of E. monostriata was not noted on polyester.

A significant interaction between the material and plate texture was found (ANOVA: $F_{2,18}=9.35$;
Fig. 5 Average number of leeches on different artificial substrates: $P C$

polycarbonate, $P E S$ polyester, $A L$ aluminium, $G L$ glass, $R U$ rubber, $S T$ steel, $P E$ polyethylene, $C E R$ ceramics, $P P$ polypropylene; statistically significant differences are indicated by different letters

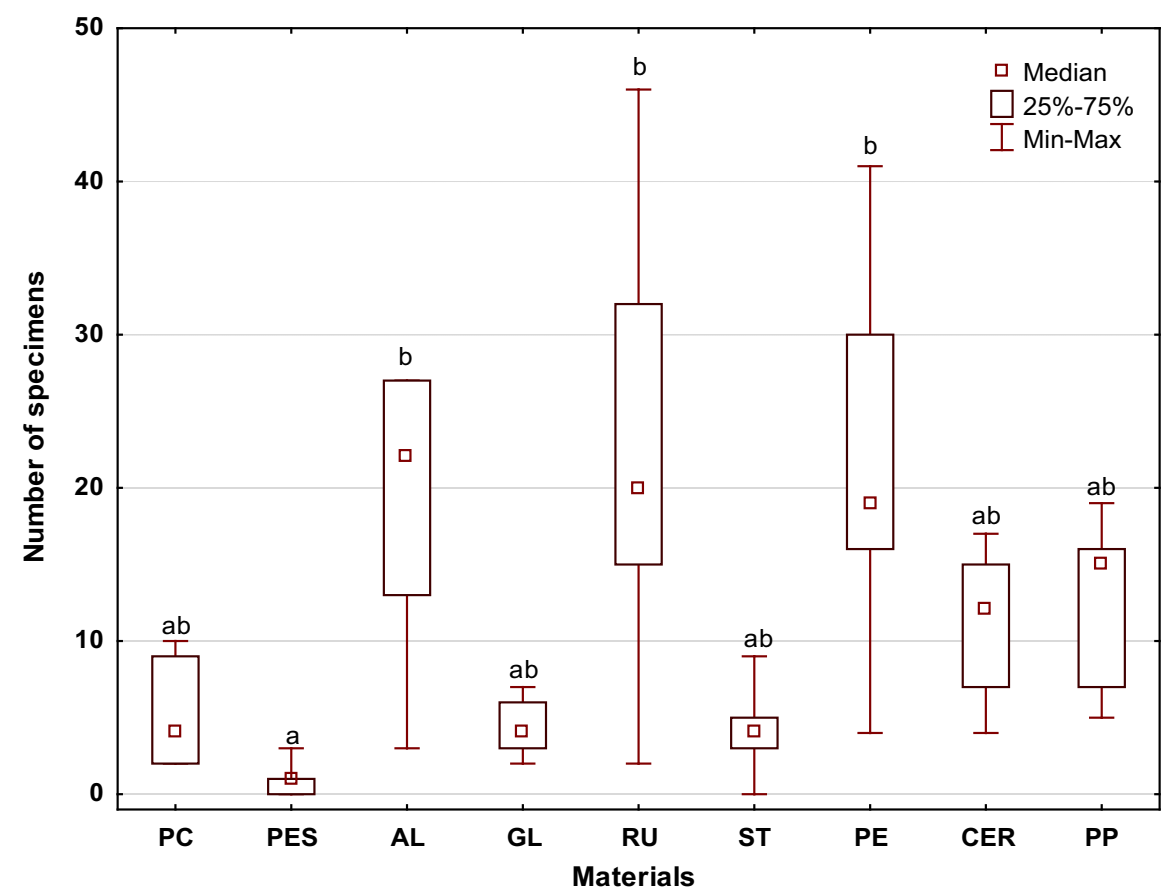


Table 2 Species composition (\%), number of individuals in the leech assemblages $(N)$ and frequency of species on different materials $(\mathrm{F})$

\begin{tabular}{|c|c|c|c|c|c|c|c|c|c|}
\hline & $\begin{array}{l}\mathrm{PC} \\
N=27\end{array}$ & $\begin{array}{l}\text { PES } \\
N=5\end{array}$ & $\begin{array}{l}\mathrm{AL} \\
N=92\end{array}$ & $\begin{array}{l}\mathrm{GL} \\
N=22\end{array}$ & $\begin{array}{l}\mathrm{RU} \\
N=115\end{array}$ & $\begin{array}{l}\mathrm{ST} \\
N=21\end{array}$ & $\begin{array}{l}\mathrm{PE} \\
N=113\end{array}$ & $\begin{array}{l}\text { CER } \\
N=55\end{array}$ & $\begin{array}{l}\mathrm{PP} \\
N=62\end{array}$ \\
\hline E. octoculata & 40.74 & 20.00 & 41.30 & 68.18 & 50.43 & 57.14 & 48.67 & 61.82 & 53.23 \\
\hline E. nigricollis & 37.04 & 80.00 & 28.26 & 13.64 & 27.83 & 33.33 & 19.47 & 10.91 & 29.03 \\
\hline H. marginata & 3.07 & - & - & - & - & - & - & 1.82 & - \\
\hline E. monostriata & 3.07 & - & 2.17 & 4.55 & 6.09 & 9.52 & 6.19 & 5.45 & 9.68 \\
\hline H. stagnalis & 14.81 & - & 19.57 & 9.09 & 11.30 & - & 19.47 & 10.91 & 6.45 \\
\hline G. concolor & - & - & 1.09 & 4.55 & 0.87 & - & 0.88 & - & - \\
\hline E. testacea & - & - & - & - & 0.87 & - & 2.65 & 5.45 & - \\
\hline G. complanata & - & - & 2.17 & - & 1.74 & - & 1.77 & 1.82 & 1.61 \\
\hline A. striata & - & - & 1.09 & - & - & - & 0.88 & 1.82 & - \\
\hline A. heteroclita & - & - & 1.09 & - & - & - & - & - & - \\
\hline A. hyalina & - & - & 3.26 & - & - & - & - & - & - \\
\hline A. papillosa & - & - & - & - & 0.87 & - & - & - & - \\
\hline
\end{tabular}

$\overline{P C}$ polycarbonate, $P E S$ polyester, $A L$ aluminium, $G L$ glass, $R U$ rubber, $S T$ steel, $P E$ polyethylene, $C E R$ ceramics, $P P$ polypropylene

$P=0.0016)$. With regards to particular materials, a significantly higher number of leeches have been found on a structural surface than on a smooth surface of the substrates made of aluminium-Fig. 6. The average number of collected leeches on the plates of various sizes was similar (ANOVA: $F_{2,} 96=2.73$; $P=0.0699$ ) ranging from 9 on the surface of $100 \mathrm{~cm}^{2}$ to 12 on those of 400 and $900 \mathrm{~cm}^{2}$. The average density of leeches on plates of various sizes ranged from 49 (glass substrate of $900 \mathrm{~cm}^{2}$ ) to 880 individuals per $\mathrm{m}^{2}$ (aluminium substrate with an area of $100 \mathrm{~cm}^{2}$ )_Fig. 7. A significant interaction between the substrate material and its size was recorded (ANOVA: $F_{6}, 96=4.67 ; P=0.0003$ ). A higher density of leeches was found on $100 \mathrm{~cm}^{2}$ plates made of aluminium, polypropylene and glass in relation to those $900 \mathrm{~cm}^{2}$, on $100 \mathrm{~cm}^{2}$ plates made of polypropylene and glass compared to those $400 \mathrm{~cm}^{2}$ and on $400 \mathrm{~cm}^{2}$ glass surfaces with respect to those of $900 \mathrm{~cm}^{2}$. In the case of polyethylene substrates of different sizes, there were no significant differences (Fig. 7).

\section{Discussion}

Studies concerning the influence of physical parameters of the environment and types of substrates, including artificial ones, are quite common for macrozoobenthos (Bonzini et al., 2008; Jae-Hoon et al., 2013; Spagnolo et al., 2014). Much has been written about their use as a tool in the assessment of aquatic environment quality (De Pauw et al., 1994; Czerniawska-Kusza, 2004; MacDonald et al., 2012; Loke et al., 2014) or biomass production of phyto and zoobenthos (Moura et al., 2007; Plá \& Alveal, 2012). In relation to inland waters, research has mainly focused on their habitat-creation role and concerns entire groups of benthic fauna (De Pauw et al., 1986, De Pauw et al., 1994; Czerniawska-Kusza, 2004; Poznańska et al., 2009; Czarnecka et al., 2009). Studies about the preferences of particular species are still rare and tend to focus on sessile organisms (Czarnołęski et al., 2004; Kobak, 2004; Kobak \& Januszewska, 2006; Porter \& Marsden, 2008; Richards \& Beger, 2011; Braccia et al., 2014; Spagnolo et al., 2014). With regard to free-living taxa, most studies have focused on representatives of Gammaridae, especially non-native species in European waters (Devin et al., 2004; Czarnecka et al., 2010; Kobak et al., 2013), but there is still little information about leech settlement on human-made substrates.

Indirectly, we can obtain this information from research devoted to entire groups of benthic fauna, which includes representatives of Hirudinida. 
Table 3 Species preferences with respect to different types of materials
$N$ number of individuals, $\%$ percent of total colonizing assemblage, $P C$

polycarbonate, $P E S$ polyester, $A L$ aluminium, $G L$ glass, $R U$ rubber, $S T$ steel, $P E$ polyethylene, $C E R$ ceramics, $P P$ polypropylene

\begin{tabular}{|c|c|c|c|c|c|c|c|c|c|c|}
\hline & & $\mathrm{PC}$ & PES & $\mathrm{AL}$ & GL & $\mathrm{RU}$ & ST & $\mathrm{PE}$ & CER & PP \\
\hline \multirow[t]{2}{*}{ E. octoculata } & $N$ & 11 & 1 & 38 & 15 & 58 & 12 & 55 & 34 & 33 \\
\hline & $\%$ & 4.28 & 0.39 & 14.79 & 5.84 & 22.57 & 4.67 & 21.40 & 13.23 & 12.84 \\
\hline \multirow[t]{2}{*}{ E. nigricollis } & $N$ & 10 & 4 & 26 & 3 & 32 & 7 & 22 & 6 & 18 \\
\hline & $\%$ & 7.81 & 3.13 & 20.31 & 2.34 & 25.00 & 5.47 & 17.19 & 4.69 & 14.06 \\
\hline \multirow[t]{2}{*}{ H. marginata } & $N$ & 1 & - & - & - & - & - & - & 1 & - \\
\hline & $\%$ & 50 & - & - & - & - & - & - & 50 & - \\
\hline \multirow[t]{2}{*}{ E.monostriata } & $N$ & 1 & - & 2 & 1 & 7 & 2 & 7 & 3 & 6 \\
\hline & $\%$ & 3.45 & - & 6.90 & 3.45 & 24.14 & 6.90 & 24.14 & 10.34 & 20.69 \\
\hline \multirow[t]{2}{*}{ H. stagnalis } & $N$ & 4 & - & 18 & 2 & 13 & - & 22 & 6 & 4 \\
\hline & $\%$ & 5.80 & - & 26.09 & 2.90 & 18.84 & - & 31.88 & 8.70 & 5.80 \\
\hline \multirow[t]{2}{*}{ G. concolor } & $N$ & - & - & 1 & 1 & 1 & - & 1 & - & - \\
\hline & $\%$ & - & - & 25.00 & 25.00 & 25.00 & - & 25.00 & - & - \\
\hline \multirow[t]{2}{*}{ H. marginata } & $N$ & - & - & - & - & - & - & - & 1 & - \\
\hline & $\%$ & - & - & - & - & - & - & - & 100 & - \\
\hline \multirow[t]{2}{*}{ E. testacea } & $N$ & - & - & - & - & 1 & - & 3 & 3 & - \\
\hline & $\%$ & - & - & - & - & 14.29 & - & 42.86 & 42.86 & - \\
\hline \multirow[t]{2}{*}{ G. complanata } & $N$ & - & - & 2 & - & 2 & - & 2 & 1 & 1 \\
\hline & $\%$ & - & - & 25.00 & - & 25.00 & - & 25.00 & 12.50 & 12.50 \\
\hline \multirow[t]{2}{*}{ A. striata } & $N$ & - & - & 1 & - & - & - & 1 & 1 & - \\
\hline & $\%$ & - & - & 33.33 & - & - & - & 33.33 & 33.33 & - \\
\hline \multirow[t]{2}{*}{ A. heteroclita } & $N$ & - & - & 1 & - & - & - & - & - & - \\
\hline & $\%$ & - & - & 100 & - & - & - & - & - & - \\
\hline \multirow[t]{2}{*}{ A. hyalina } & $N$ & - & - & 3 & - & - & - & - & - & - \\
\hline & $\%$ & - & - & 100 & - & - & - & - & - & - \\
\hline \multirow[t]{2}{*}{ A. papillosa } & $N$ & - & - & - & - & 1 & - & - & - & - \\
\hline & $\%$ & - & - & - & - & 100.00 & - & - & - & - \\
\hline
\end{tabular}

Nevertheless, there is a lack of data about leech preferences to artificial substrates. To the authors' knowledge, this is the first time such an analysis has been conducted on this group of organisms. According to the literature, some taxa are more numerous on artificial substrates in relation to the natural bottom (Czarnecka et al., 2009); this particularly applies to thigmotactic organisms, which include leeches (Czerniawska-Kusza, 2004). In general, they inhabit tightfitting places to achieve maximum body contact (Bisson \& Torre, 2011).

This study indicates that leech assemblages on artificial substrates are dominated by predatory taxa. Although the collected material was characterized by high species diversity and rare species of leeches were found (Alboglossiphonia hyalina, A. striata and A. papillosa), the only representative of bloodsucking taxa was Hemiclepsis marginata. However, several previous studies have already indentified other species in this reservoir belonging to this particular trophic guild (Żółtowski, 1965; Bielecki \& Dzika, 2000; Bielecki et al., 2011b). Difference in the species composition, described by us in comparison with previous research, may result from the fact that abovementioned authors used several different methods of collection of leeches including sampling directly from the fish hosts and manually from submerged elements of the environment. Koperski (2003) explained the absence of bloodsuckers on artificial substrates by unequal and concentrated distribution, but in our opinion, their physiological state is equally important. When hungry, bloodsucker species emerge from their hiding places beneath submerged substrates and move to habitats where contact with a host is more probable (Mann, 1962). More often they occur on the external surfaces of solid elements of the environment, near the 
Fig. 6 Average number of leeches on substrates of different textures: $S M$ smooth, $R O$ rough/riffled, $R U$ rubber, $G L$ glass, $A L$ aluminium; statistically significant differences are indicated by different letters; error bars indicate confidence levels of 0.95

Fig. 7 Average density of leeches on substrates of various sizes made of different materials: $A L$ aluminium, $P E$ polyethylene, $P P$ polypropylene, $G L$ glass; statistically significant differences are indicated by different letters; error bars indicate confidence levels of 0.95
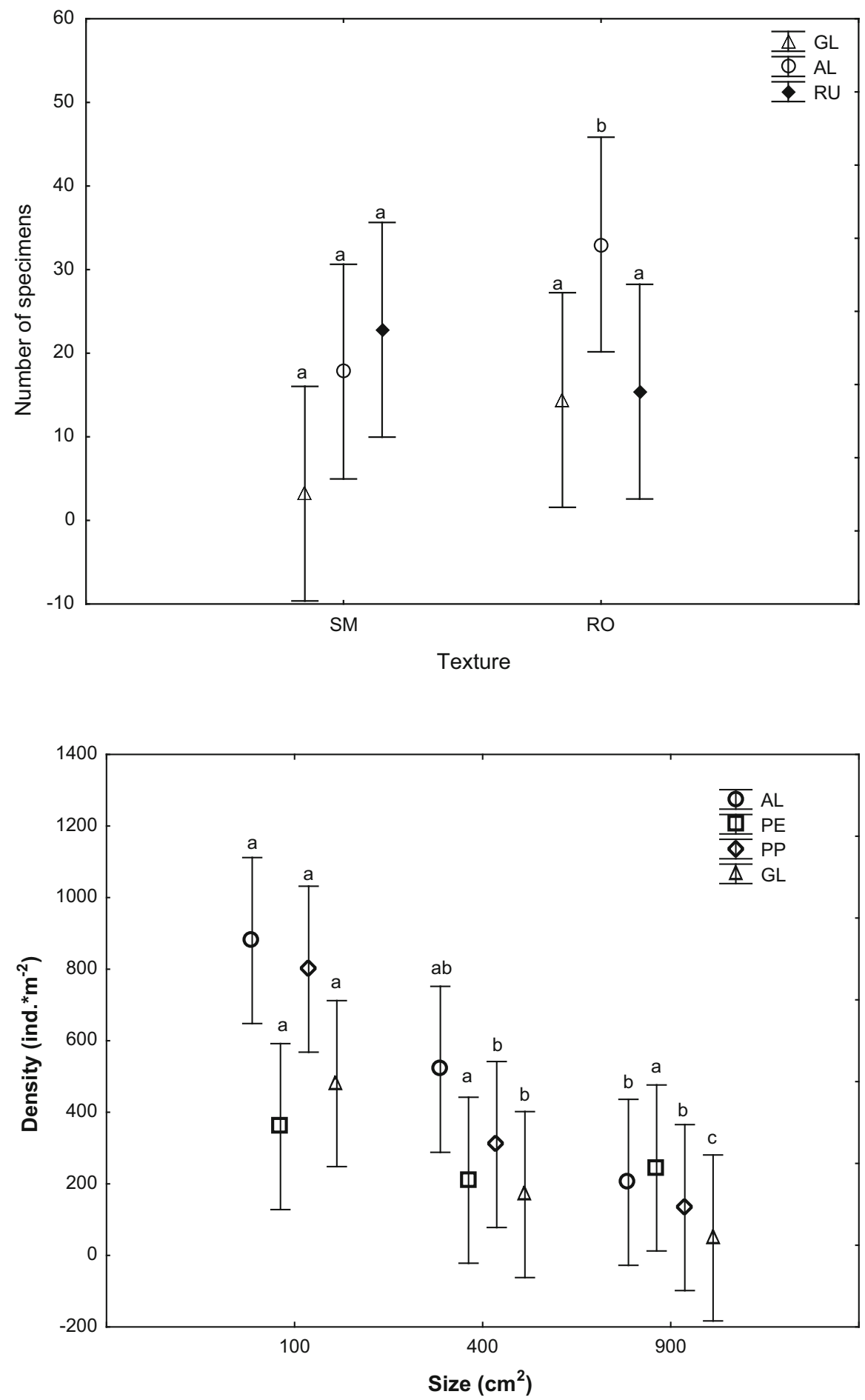

water surface or reservoir banks, where they wait for their host (Pawłowski, 1936; Bielecki, 1999; Bielecki et al., 2011a). Therefore, we would conclude that
Piscicola leeches were not found in our samples as they are likely attached to their hosts, which are consistent with their life cycles. The other species may 
not stay near the bottom zone and, as a result, they were beyond the range of the experiment.

In our experiment, all collected species on artificial substrates represent two morphological body forms: "leaf" (genus Alboglossiphonia, Glossiphonia, Hemiclepsis, Helobdella) and "tape" (Erpobdella) (division in accordance with Bielecki, 1997). Possibly, due to the strong dorsoventrally flattened body, these two forms show a greater affinity for the hard substrate than other shapes found in leeches and are more dependent on it, which is associated with their frequent settlement on artificial substrates. The cylindrical form was not recorded during the study.

An important factor which could influence the density and the composition of the leech community in artificial habitats is the presence of periphyton. The results of Koperski (2003) have shown that a significantly lower density of molluscivorous species is reported on the artificial substrates with poorly developed biofilm. The presence of biofouling algae entailed an increase in the individuals of snails and thus of leeches of the family Glossiphoniidae, which feed on their body fluids. In turn, a thick layer of periphyton hinders capturing success and feeding rates of omnivorous leeches of the genus Erpobdella and Helobdella, resulting in their greater number on substrates with a less-developed layer of biofouling algae (Koperski, 2003), which is confirmed in our study. In our experiments, periphyton may develop only in small degrees on settlement units exposed to the environment for about 2 weeks, which makes them unattractive for gastropods and thus for molluscivores of the Glossiphoniidae family. This is probably why during the experiment a dominance of omnivorous species such as E. octoculata, E. nigricollis, E. monostriata and H. stagnalis was noted.

Our research has shown that leeches inhabit structural substrates in greater numbers than smooth ones. Similar to many other benthic species (Marsden \& Lansky, 2000; Czarnołęski et al., 2004; Saliu \& Ovuorie, 2006), leeches prefer this texture type because of the quick and intensive development of the biofouling alga layer. Despite the low development of periphyton during the experiment, it could spread more on a rough surface. Bergey (1999) showed that small crevices on rough surfaces are used by the diatoms as refuge against water waves and grazer pressure, resulting in more intensive development of periphyton on less smooth surfaces. Hart (1978),
Clifford et al. (1989) and Bergey (1999) noted that small aquatic organisms and detrital particles accumulate in depressions on rough surfaces which result in greater diversity and abundance of macroinvertebrates. Thus, an increase in food resources can be a key factor in more numerous occurrences of both predator and parasite leeches.

In our study, the most densely inhabited substrates were rubber, polyethylene and aluminium, and the least frequently colonized was polyester. This tendency is consistent with observations of other authors (Pawłowski, 1936; Mann, 1962; Sawyer, 1986; Czarnecka et al., 2009; Koperski, 2010) and confirms preferences for the hard surfaces. Leeches less frequently colonize a soft substrate, subjected to the movements of water masses. This finding was consistent with the results of Czarnecka et al. (2009), who showed that there were no leeches on soft materials such as cotton, nylon or linen. Unstable substrates decrease their ability to move, escape or obtain food (Agapow, 1980). This is especially important for predatory leeches of the genus Helobdella and Erpobdella (Adamiak-Brud et al., 2014). Notwithstanding, substrates made of glass and polycarbonate are hard and guarantee sufficient stability, Hirudinida settled on them in a relatively small number may be because of the greater amount of solar radiation. All of the above-mentioned materials were transparent, which prevents settlement for negative phototactic leeches (Pawłowski, 1936; Mann, 1962; Elliott, 1973; Sawyer, 1986).

The results of field experiments on leech density on substrates of different sizes have shown that smaller plates have significantly higher densities of individuals. This may be due to several factors, primarily leeches tend to inhabit the edges of various submerged elements, which were observed in our study (GarciaPerez et al., 2007; Bisson \& Torre, 2011). The substrate is even more attractive for them, when circumference to the surface area ratio is higher, which ensures a greater availability of attractive places for leeches to inhabit. Perhaps there is a minimum size of objects of a substrate element beyond which leeches are unable to occupy; this may be conditioned by body size, reduction of movement capacity, etc.

Leech density also depends on the presence of conspecifics (Lang, 1974; Garcia-Perez et al., 2007; Bisson \& Torre, 2011; Bisson et al., 2012). When choosing a place to colonize, leeches actively penetrate 
micro-habitats (Garcia-Perez et al., 2007). If this exploratory phase is accompanied by sufficient physical contact with conspecifics, leeches form a group and inhabit such regions (Bisson \& Torre, 2011; Bisson et al., 2012). In order to settle they must exceed a certain threshold of meetings. Too few contacts result in further exploration and selection of another place (Bisson \& Torre, 2011). The smaller plates have a higher leech density, and since they are more crowded, it is easier to have direct contact between individuals. It should be emphasized that a group enhances their stability and lifetime in a particular micro-habitat by adding successive specimens (Bisson et al., 2012). This mechanism is connected with the secretion of neuromodulators, serotonin 5-HT and to a lesser extent dopamine into the bloodstream of individuals during physical contact with members of the same taxon (Bisson \& Torre, 2011; Bisson et al., 2012). The benefits of group formation by leeches are not understood, but Bisson et al. (2012) have observed a seasonal variation in the creation of social agglomeration. In late spring and summer, leeches are more active and prone to social behaviour, while in the winter their mobility and willingness to form groups slightly decrease. This may indicate that gregariousness plays a role in finding a sexual partner. However, there is still a lack of information whether encounters with individuals of other species of Hirudinida initiate the agglomeration and affect the choice of location for settlement.

In conclusion, all our hypotheses have been corroborated. We confirm that leech abundance depends on the type of material, from which the artificial substrates are made, and their texture. There is a high probability that leeches numerously inhabit hard anthropogenic substrates such as rubber, polyethylene and aluminium with a rough surface. The density of these organisms is also affected by the size of artificial objects. Indeed, leeches prefer smaller elements. The above considerations provide information on artificial substrates from the point of view of their attractiveness for leeches. They can become a theoretical base that supports the preparation of anthropogenic substrates for collecting representatives of Hirudinida and analysing water quality with biotic indices. Improvement of sampling methods is important because until now the universal method of quantitative leech collection has not yet been developed and current methods have many limitations.
Open Access This article is distributed under the terms of the Creative Commons Attribution 4.0 International License (http:// creativecommons.org/licenses/by/4.0/), which permits unrestricted use, distribution, and reproduction in any medium, provided you give appropriate credit to the original author(s) and the source, provide a link to the Creative Commons license, and indicate if changes were made.

\section{References}

Adamiak-Brud, Ż., A. Bielecki \& I. Jabłońska-Barna, 2014. The impact of environmental factors on the formation of leech assemblages (Hirudinida) in freshwater reservoirs [in Polish]. Dokonania Młodych Naukowców 2: 104-109.

Agapow, L., 1980. The leeches (Hirudinea) of the central and lower Odra River [in Polish]. Zeszyt Nauk Uniwersytetu Łódźkiego 3: 105-122.

Beaven, L., J. Sadler \& C. Pinder, 2000. The invertebrate fauna of a physically modified urban river. Hydrobiologia 445: 97-108.

Beracko, P. \& V. Košel, 2011. Life cycle and feeding habits of Dina punctata JOHANSSON, 1927 (Erpobdellidae, Hirudinea) in a small Carpathian stream. International Review of Hydrobiology 96: 39-47.

Bergey, E. A., 1999. Crevices as refugia for stream diatoms: Effect of crevices size on abraded substrates. Limnology and Oceanography 44: 1522-1529.

Bertman, M. \& A. Bielecki, 1997. The leeches (Hirudinea) of the water reservoirs of Kielce and its neighbourhood [in Polish]. Rocznik Świętokrzyski Seria B- Nauki Przyrodnicze 24: 45-49.

Bielecki, A., 1997. Fish leeches of Poland in relation to the Palearctic piscicolines (Hirudinea: Piscicolidae: Piscicolinae). Genus 8: 223-375.

Bielecki, A., 1999. The role of eyespots in prey searching in parasite leeches (Hirudinea, Piscicolidae) [in Polish]. Wiadomości Parazytologiczne 45: 339-345.

Bielecki, A. \& E. Dzika, 2000. The fish leeches (Hirudinea: Piscicolidae i Glossiphoniidae) of the Lakes Ukiel, Warniak and Wulpińskie. Preliminary studies. Wiadomości Parazytologiczne 46: 123-126.

Bielecki, A., A. Jawniak \& J. Kalinowska, 2004. The leeches (Hirudinea) of the "Karas Lake" reserve in Poland. Lauterbornia 52: 33-38.

Bielecki, A., K. Palińska \& D. Marczak, 2008. The leeches (Hirudinida) of Slowinski National Park [in Polish]. Parki Narodowe i Rezerwaty Przyrody 27: 35-41.

Bielecki, A., J. M. Cichocka, J. Terlecki \& A. Witkowski, 2011a. Invasion of the leech Piscicola respirans Troschel, 1850 (Hirudinea, Piscicolidae) on fins european grayling Thymallus thymallus (L.). Biologia 66: 292-298.

Bielecki, A., P. Świątek, J. M. Cichocka, E. Ropelewska, I. Jeleń $\& \dot{Z}$. Adamiak-Brud, 2011b. The leeches of surface waters of Olsztyn [in Polish]. Forum Faunistyczne 1: 12-34.

Bisson, G. \& V. Torre, 2011. Statistical characterization of social interactions and collective behaviour in medicinal leeches. Journal of Neurophysiology 106: 78-90. 
Bisson, G., G. Bianconi \& V. Torre, 2012. The dynamics of group formation among leeches. Frontiers in Physiology 3: 133.

Bonzini, S., A. Finizio, E. Berra, M. Forcella, P. Parenti \& M. Vighi, 2008. Effect of river pollution on the colonisation of artificial substrates by macrozoobenthos. Aquatic Toxicology 89: 1-10.

Braccia, A., S. L. Eggert \& N. King, 2014. Macroinvertebrate colonization dynamics on artificial substrates along an algal resource gradient. Hydrobiologia 727: 1-18.

Brauns, M., X. P. Garcia, N. Waltz \& M. Pusch, 2007. Effect of human shoreline development on littoral macroinvertebrates in lowland lakes. Journal of Applied Ecology 44: 1138-1144.

Brönmark, C., 1992. Leech predation on juvenile freshwater snails: effects of size, species and substrate. Oecologia 91: 526-529.

Chapman, M. G. \& B. G. Clynick, 2006. Experiments testing the use of waste material in estuaries as habitat for subtidal organisms. Journal of Experimental Marine Biology and Ecology 338: 164-178.

Chernaya, L. V. \& L. A. Koval'chuk, 2009. Distribution of leeches in aquatic ecosystems of the City of Yekaterinburg and its vicinity. Russian Journal of Ecology 40: 111-115.

Clifford, H. F., V. Gotceitas \& R. J. Casey, 1989. Roughness and colour of artificial substratum particles as possible factors in colonization of stream invertebrates. Hydrobiologia 1975: 89-95.

Czarnecka, M., M. Poznańska, J. Kobak \& N. Wolnomiejski, 2009. The role of solid waste materials as habitats for macroinvertebrates in a lowland dam reservoir. Hydrobiologia 635: 125-135.

Czarnecka, M., J. Kobak \& R. Wiśniewski, 2010. Preferences of juveniles and adults of the invasive Ponto-Caspian amphipod Pontogammarus robustoides for various species of macrophytes and artificial substrata. Hydrobiologia 655: 79-88.

Czarnołęski, M., Ł. Michalczyk \& A. Pajdak-Stoś, 2004. Substrate preference in settling zebra mussel Dreissena polymorpha. Archiv für Hydrobiologie 159: 263-270.

Czerniawska-Kusza, I., 2004. Use of artificial substrates for sampling benthic macroinvertebrates in the assessment of water quality of large lowland rivers. Polish Journal of Environmental Studies 13: 579-584.

De Pauw, N., D. Roels \& P. Fontoura, 1986. Use of artificial substrates for standardized sampling of macroinveretebrates in the assessment of water quality by the Belgian Biotic Index. Hydrobiologia 133: 237-258.

De Pauw, N., V. Lambert \& A. Van Kenhove, 1994. Performance of two artificial substrate samplers for macroinvertebrates in biological monitoring of large and deep rivers and canals in Belgium and The Netherlands. Environmental Monitoring and Assessment 30: 25-47.

Devin, S., C. Piscart, J. Betsel \& J. Moreteau, 2004. Life history traits and of the invader Dikerogammarus villosus (Crustacea: Amphipoda) in the Moselle River, France. International Review of Hydrobiology 89: 21-34.

Dimitriu, C. \& D. H. Shain, 2004. Ultrastructure properties of the Theromyzon (Annelida: Hirudinae) coccon membrane. Micron 35: 281-285.
Elliott, J. M., 1973. The diel activity pattern, drifting and food of the leech Erpobdella octoculata (L.) (Hirudinea: Erpobdellidae) in a Lake District stream. Journal of Animal Ecology 42: 449-459.

Garcia-Perez, E., A. Mazzoni \& V. Torre, 2007. Spontaneous electrical activity and behaviour in the leech Hirudo medicinalis. Frontiers in Integrative Neuroscience 1: 8 .

Hart, D. D., 1978. Diversity of stream insects: regulation by rock size and microspatial complexity. Verhandlungen des Internationalen Verein Limnologie 20: 1376-1381.

Jae-Hoon, C., K. Kwang-Bae, S. Ji-Na, K. In-Soo, S. Jeong-Bin \& K. Chul-Hwi, 2013. Comparative study on the fauna composition of intertidal invertebrates between natural and artificial substrata in the Northeastern Coast of Jeju Island. Ocean Science Journal 48: 319-328.

Jatulewicz, I., 2007. Comparison of macroinvertebrate communities associated with various habitats in anthropogenic reservoirs. Oceanological and Hydrobiological Studies 36: 39-47.

Kobak, J., 2004. Recruitment and small-scale spatial distribution of Dreissena polymorpha (Bivalvia) on artificial materials. Archiv für Hydrobiologie 160: 25-44.

Kobak, J. \& M. Januszewska, 2006. Impact of substratum type on attachment and survival of Dreissena polymorpha (Bivalvia). Folia Malacologica 14: 51-56.

Kobak, J., T. Kakareko, Ł. Jermacz \& M. Poznańska, 2013. The impact of zebra mussel (Dreissena polymorpha) periostracum and biofilm cues on habitat selection by a PontoCaspian amphipod Dikerogammarus haemobaphes. Hydrobiologia 702: 215-226.

Koperski, P., 2003. Stone-dwelling leeches (Hirudinea, Clitellata) of Lake Hańcza (Poland): different sampling methods determine different taxonomic structures. Polish Journal of Ecology 51: 353-361.

Koperski, P., 2010. Diversity of macrobenthos in lowland streams: ecological determinants and taxonomic specificity. Journal of Limnology 69: 88-101.

Krodkiewska, M., 2003. Leech (Hirudinea) communities of post-exploration water bodies in industrial region (Upper Silesia, Poland). Polish Journal of Ecology 51: 101-108.

Lang, C., 1974. Macrofaune des fonds de cailloux du Léman. Swiss Journal of Hydrology 36: 301-350.

Loke, L. H. L., N. R. Jachowski, T. J. Bouma, R. J. Ladle \& P. A. Todd, 2014. Complexity for artificial substrates (CASU): Software for creating and visualising habitat complexity. Plos One 9: e87990.

MacDonald, L. A., A. M. Balasubramaniam, R. I. Hall, B. B. Wolfe \& J. N. Sweetman, 2012. Developing biomonitoring protocols for shallow Artic lakes using diatoms and artificial substrate samplers. Hydrobiologia 638: 231-248.

Marsden, J. \& D. Lansky, 2000. Substrate selection by settling zebra mussels, Dreissena polymorpha, relative to material, texture, orientation, and sunlight. Canadian Journal of Zoology 78: 787-793.

Mann, K. H., 1962. Leeches (Hirudinea) their structure, physiology, ecology and embriology. Pergamon Press, New York.

Mason, T. A., C. W. Sayers, T. L. Paulson, J. Coleman \& D. H. Shain, 2005. Cocoon deposition and hatching in the aquatic leech Theromyzon tessulatum (Annelida, 
Hirudinea, Glossiphoniidae). The American Midland Naturalist 154: 78-87.

Matysiak, K., 1985. The impact of bottom type and seasonal conditions on the occurrence of leech species (Hirudinea) in lowland streams of the basin Narewka [in Polish]. Przegląd Zoologiczny 29: 55-67.

Mazzoni, A., E. Garcia-Perez, D. Zoccolan, S. Graziosi \& V. Torre, 2005. Quantitative characterization and classification of leech behaviour. Journal of Neurophysiology 93: 580-593.

Moura, A., D. Boaventura, J. Cúrdia, S. Carvalho, L. Cancela de Fonseca, F. M. Leitão, M. N. Santos \& C. C. Monteiro, 2007. Effect of depth and reef structure on early macrobenthic communities of the Algarve artificial reefs (southern Portugal). Hydrobiologia 580: 173-180.

Pawłowski, L. K., 1936. Freshwater Fauna of Poland. Leeches [in Polish]. Wydawnictwo Kasy Imienia Mianowskiego Instytutu Pobieranie Nauki Warszawa.

Plá, P. C. \& K. Alveal, 2012. Development of Macrocystis pyrifera from spores and gametes on artificial substrate. Algal production in a surface culture. Latin American Journal of Aquatic Research 40: 292-299.

Porter, A. E. \& J. E. Marsden, 2008. Zebra mussel (Dreissena polymorpha) avoid attachment to mesh materials. Northeastern Naturalist 15: 589-594.

Poznańska, M., J. Kobak, N. Wolnomiejski \& T. Kakarenko, 2009. Shallow-water benthic macroinvertebrate community of the limnic part of a lowland Polish dam reservoir. Limnologica 39: 163-176.

Richards, Z. T. \& M. Beger, 2011. A quantification of the standing stock of macro-debris in Majuro lagoon and its effect on hard coral communities. Marine Pollution Bulletin 62: 1693-1701.
Saliu, J. K. \& U. R. Ovuorie, 2006. The artificial substrate preference of invertebrates in Ogbe Creek, Lagos, Nigeria. Life Science Journal 4: 77-81.

Sawyer, R. T., 1986. Leech biology and behaviour., Feeding Biology, Ecology and Systematics Clarendon Press, Oxford.

Siciński, J., 2009. Annelids Annelida. [in Polish]. In Błaszak, C. (eds) Zoology: Invertebrates. Wydawnictwo Naukowe Warszawa.

Spagnolo, A., C. Cuicchi, E. Punzo, A. Santelli, G. Scarcella \& G. Fabi, 2014. Patterns of colonization and succession of benthic assemblages in two artificial substrates. Journal of Sea Research 88: 78-86.

Strzelec, M., A. Spyra \& W. Serafińska, 2010. Biology of the inlands waters. A textbook for students of the I and II level of graduated studies on faculties of Biology and Environmental Protection [in Polish]. Wydawnictwo Uniwersytetu Śląskiego Katowice.

Utevsky, S. Y., M. O. Son, V. G. Dyadichko \& J. A. Kaygorodova, 2012. New information on the geographical distribution of Erpobdella vilnensis (Liskiewicz, 1915) (Hirudinida, Erpobdellidae) in Ukraine. Lauterbornia 75: 75-78.

Winston, J. E., 1982. Driftt plastic- an expanding niche for a marine invertebrate? Marine Pollution Bulletin 13: 348-357.

Young, J. O., 1988. Intra- and interspecific predation of the cocoon of Erpobdella octoculata (L.) (Annelida: Hirudinea). Hydrobiologia 169: 85-89.

Żółtowski, M., 1965. The occurrence of leech Haementeria costata (Fr. Múller) on the Ełk Lakeland District [in Polish]. Zeszyty Naukowe WSR Olsztyn 20: 145-150. 